\title{
Hydro-Geoelectrical Study for Groundwater Potential of Lassa And Environs, North Eastern Nigeria
}

\author{
A. Nur, A. Taiyib and I. S. Nggada
}

\section{ABSTRACT}

Twenty-two Vertical Electrical Sounding (VES) were carried out to evaluate groundwater potential and aquifer protective capacity of the overburden units using Schlumberger configuration. It was observed that H-curve is the dominant curve type in the study area. The Geo-electro stratigraphic section revealed that the geologic sequence beneath the study area is composed of topsoil, highly weather basement, partly fractured basement and fresh basement. The first layer has an average thickness and resistivity of $1 \mathrm{~m}$ and $130 \Omega \mathrm{m}$, respectively. The second layer has an average thickness of $14 \mathrm{~m}$ and an average resistivity of $53 \Omega \mathrm{m}$. The third layer is partly fracture basement with an average resistivity of $747 \Omega \mathrm{m}$ while at some VES point represents fresh basement. The highly weathered basement and partly fracture basement layer make up the water bearing formation of the area. Dar-Zarrouk parameter revealed that the area under study has protective capacity range from weak to good capacity of the overburden material. Areas that are classified as poor and weak are indicative areas are thus vulnerable to infiltration of leachate and other surface contaminations. The groundwater potential of the area ranges from low to moderate potential; the moderate zone constitutes $86 \%$ while the low potential constitutes $14 \%$ of the study area. The transverse resistance within the study area ranges from 119.6 to $6983.7 \mathrm{ohms}-\mathrm{m}^{2}$ with an average value of $1024.59 \mathrm{ohms}-\mathrm{m}^{2}$. Hydraulic conductivity values determined from geoelectrical technique range from 3.05 to $38.04 \mathrm{~m} / \mathrm{day}$ with an average value of $14.86 \mathrm{~m} / \mathrm{day}$.

Published Online: September 28, 2021

ISSN: $2684-446 \mathrm{X}$

DOI : $10.24018 /$ ejgeo.2021.2.5.181

A. Nur

Department of Geology, Modibbo Adama University of Technology (MAUTECH), Yola, Nigeria.

(e-mail: anur@mautech.edu.ng)

A. Taiyib

Modibbo Adama University of Technology (MAUTECH), Yola, Nigeria. (e-mail: taiyibabubakar@gmail.com) I. S. Nggada *

Enviplan International Limited, No: 12A Degel 2 Roag U/Rimi GRA Kaduna. Kaduna State, Nigeria.

(e-mail: ibrahimsikami@ ${ }^{\circledR}$ ahoo.com)

*Corresponding Author

Keywords: Dar-Zarrouk, Geo-electrostratigraphi, Lassa, Protective Capacity, VES.

\section{INTRODUCTION}

The area under investigation falls within 1964 sheet of Federal Survey of Nigeria. It is situated in the North eastern part of Nigeria in Borno state located between longitudes $13^{\circ}$ $07^{\prime}-13^{\circ} 17^{\prime} \mathrm{E}$ and latitudes $10^{\circ} 40^{\prime}-10^{\circ} 54^{\prime} \mathrm{N}$. It occupies an area of $336.6 \mathrm{sq} \mathrm{km}$. The area is accessible via the Uba-Askira road (Fig. 1) in the northern part of the Borno basement region.

Water is a highly mobile and variable resource that exists on the surface of the earth and within the subsurface in the pore spaces of geologic materials of the earth. Water beneath the subsurface generally occurs within water bearing porous and permeable rocks called aquifers. Examples of such rocks include sedimentary rocks like sandstone. However, fractured basement rocks and weathered basement rocks can also be classified as aquifers. Water is an indispensable resource and the concern of many earth scientists and researchers has been on the acquisition of a reliable source The climate of the area is sub Sudan climatic zone characterized by wet and dry seasons. Most of the rain falls during the months of May to September but small amounts fall in March, April, October, and November. The remaining months of the year are dry. It is worthy to note that the Askira plain lies partly within the rain shadow of the Biu Plateau to the west and for this reason, there is a marked increase in mean annual rainfall from North to South. Temperatures are extreme in the area; however, the coldest night of the year occurs in the months of December and January during which air is often hazy and visibility is poor due to fine particles of dust. During this period, temperatures range from $21{ }^{\circ} \mathrm{C}$ to $25^{\circ} \mathrm{C}$ while at night, it could be as low as $14^{\circ} \mathrm{C}$, though, at higher altitudes [3]. March to June experiences an increase in temperature as the rainy season set in the daily maximum temperature up to $44^{\circ} \mathrm{C}$.

of drinking water [1].

Domestic water supply in Lassa and environs comes largely from the groundwater; much of this is taken from the overburden and fractured granite. Over the years, boreholes and water wells have been drilled with or without previous knowledge of the subsurface information due to multiple failed boreholes, research efforts grew to minimize failed wells thereby reducing the risks as well as reducing the cost of drilling abortive wells. The use of geoelectrical data can give the approximate depth to aquifer [2].

Information concerning the lithology, stratigraphic sequence and hydro-geological characteristics of the subsurface material can be provided through the aid of electrical resistivity prospecting method. This geophysical method determines the variation in the subsurface 
distribution of electrical properties within the homogenous entity of the earth. This study, therefore, involves the use of the resistivity geophysical method, specifically the Schlumberger array to assess the average thickness of the aquifers within the study area so that apart from investigating the locations of these water bearing formations, it will show how they occur beneath the subsurface in Lassa and environs, hence contributing to a better understanding of the geological characteristics of the areas.

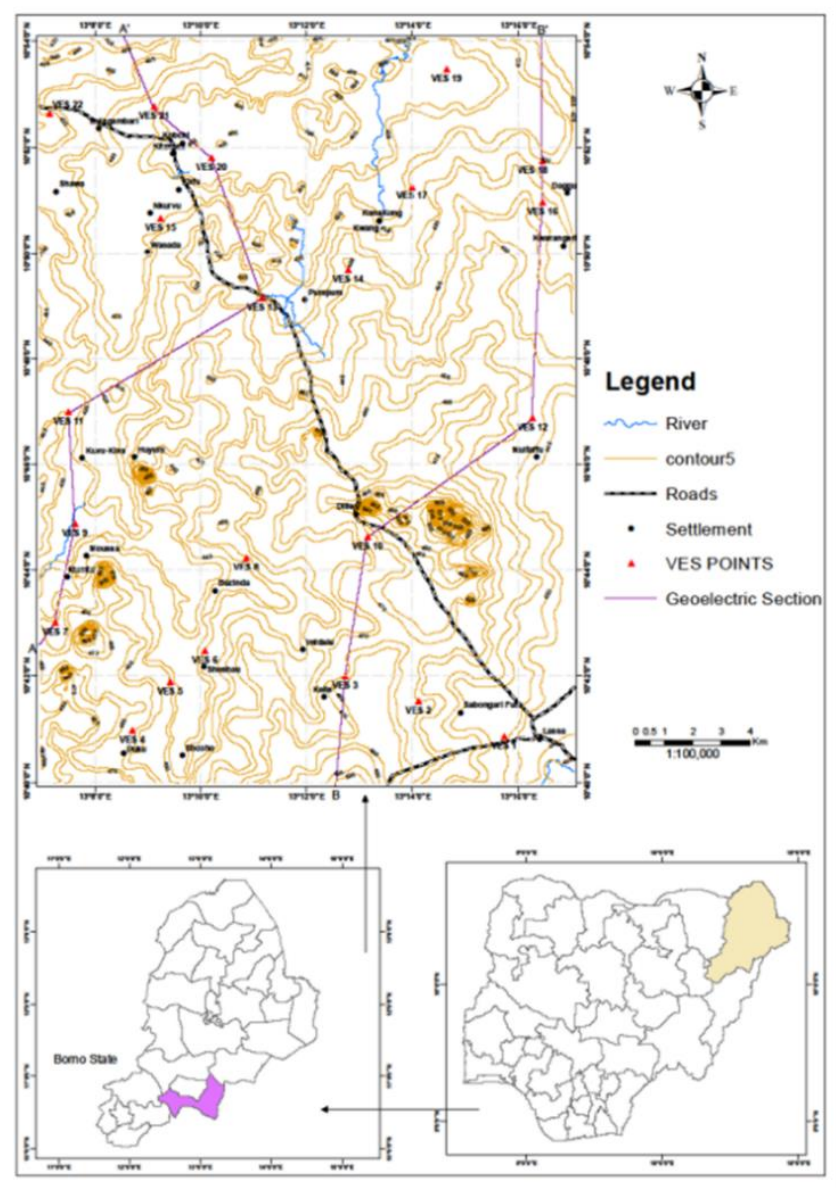

Fig. 1. Topographic Map of the Study Area (USA Geological Survey Agency (2010).

The aim of this study is to investigate the groundwater potential of Lassa town and environs of Borno State and relate the resistivities and thicknesses of water bearing layer that are favourable for groundwater development.

\section{General Geology of the Area}

The area is located within the eastern province of the basement complex of north-eastern Nigeria, and most rocks belong to the older granites of the Pan African Orogeny. The granitic rocks have undergone complete weathering leading to unconsolidated weathered overburden consisting of sands, clays, and laterite. The basement complex of the eastern province is divided into the Mandara Mountain, Alantika Mountain, Shebshi Mountain, and the Adamawa Massif according to Carter et al. [4].

The geology is made up of the Precambrian basement complex rocks which are considered to be undifferentiated basement complex mainly gneisses, migmatite, and granites. The gneiss-migmatite complex is the most widespread and occupies more than half of the area and is the oldest rock in the area. They are heterogeneous rock group, which is composed gneiss migmatite of various origin and series of metamorphosed basic and ultra-basic rocks. Most of the basement complex of the area is dominated by biotitic granite, which is light gray, very coarse grained and occasionally pegmatitic and aplitic. Porphoric feldspar is occasionally present, and some places show a generally parallel alignment. The vegetation consists of large isolated trees and shrubs of savannah type which tend to thicken along the drainage line and at the foot of the hills. Reference [3] reported that Mylonite occupies a narrow shear zone trending north-south.

During field work the rocks identified in the study area are crystalline rocks as the basement complex which makes up the African shield composed of Alluvium, medium to coarse grained granite, fine grained granite and porphyritic granite (Fig. 2). The fine grained granite occurs at the South-western part of the study area around Mumtal as intrusive bodies characterized by numerous bodies of mafic minerals, there are also thick deposits of alluvium as exposed along a stream channels.

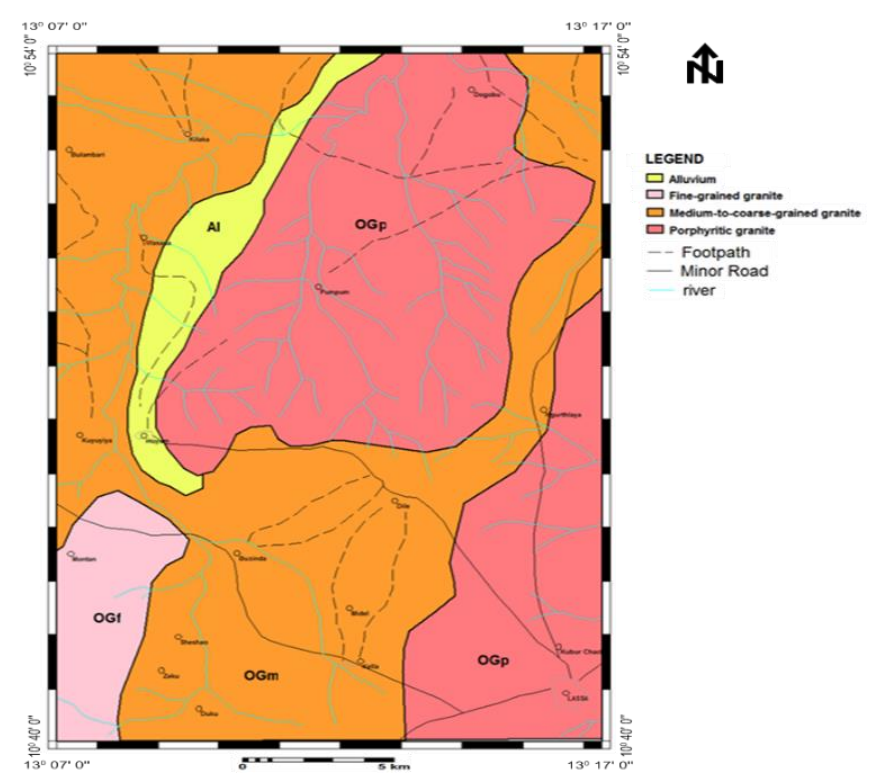

Fig. 2. Geologic Map of the Study Area (Field work).

\section{MethodolOGY}

The application of the resistivity methods has proved effective and a rapid tool for investigation and exploration for borehole location in basement terrain and also had some success in sedimentary rocks for lithologic variations and location of fracture zones [5]. The use of the resistivity method gives a better understanding of the hydrogeology of the basement area. It can furnish information on the subsurface geology that cannot be obtained by other methods in geophysics. The electrical properties of rocks depend on the amount of water, conducting minerals and the resistivity varies with salinity and temperature. Reference [5] adopted the electrical resistivity method to investigate the geoelectrical parameters and hydro-geologic characteristics of parts of the basement complex terrain of Nigeria and identified five aquifer units. Other researchers [6]-[9] have utilized resistivity methods as a tool for groundwater 
exploration in basement terrain where the occurrences of groundwater is due largely to the development of secondary porosity and permeability of the weathering and/or fracturing of the parent basement rocks.

Terrameter SAS 300 system was used in the field for the purpose of the survey; the electrodes were arranged along a straight line and systematically disposed of with respect to the centre of configuration. Geophysical technique of the electrical resistivity method of Schlumberger array method was conducted in 22 different locations within the area. The resistance from each sounding was multiplied by the geometric factor $(\mathrm{k})$ corresponding to each electrode spacing to obtain the apparent resistivity $\left(\rho_{\mathrm{a}}\right)$ values needed in plotting the Vertical Electrical Sounding (VES) curves.

\section{RESUlTS AND DisCUSSION}

The results obtained from the computed output of twentytwo VES in Lassa town and environs North Eastern Nigeria is presented in Table I. The curve types obtained were predominantly $\mathrm{H}$ types which include VES1, VES2, VES3, VES4, VES5, VES6, VES7, VES8, VES9, VES10, VES11, VES12, VES13, VES14, VES16, VES18, VES19, VES20,
VES21 and VES22 constituting $90.9 \%$ of the study area with one A type at VES 15 representing $4.55 \%$ and one $\mathrm{K}$ type at VES 17 representing $4.55 \%$ of the study area. First-order geometric parameters (resistivity and thickness) of all sounded points which contain details of layer thicknesses, resistivity, longitudinal conductance, transverse resistivity, and fitting error for all the points sounded in the area are shown in (Table I). Iso-Resistivity map and Geo-electric sections have been drawn on the basis of interpreted VES data.

\section{A. Iso-Resistivity Maps}

Iso -resistivity maps were prepared using surfer software by plotting the resistivity obtained from sounding curves at a given electrode spacing common to all the sounding points for $A B / 2=40 \mathrm{~m}$ and $A B / 2=100 \mathrm{~m}$ (Fig. 3 a and $3 \mathrm{~b}$ ) in the area and the points of equal resistivity were contoured. High resistivity values were observed at the western part of the maps whereas the northern, southern eastern parts were characterized by low resistivity values. This means that there is high conductivity in the southern parts of the area as opposed to the western part.

TABLE I: RESULT OBTAINED FROM COMPUTED OUTPUT OF TWENTY TWO (22) VES POINT WITHIN LASSA TOWN AND ENVIRONS

\begin{tabular}{|c|c|c|c|c|c|c|c|c|c|c|c|c|c|}
\hline \multirow[t]{2}{*}{ S/No } & \multirow[t]{2}{*}{$\begin{array}{l}\text { VES } \\
\text { Point }\end{array}$} & \multirow[t]{2}{*}{ Coordinates } & \multicolumn{2}{|c|}{$\begin{array}{l}\text { Thickness of } \\
\text { Layers (m) }\end{array}$} & \multicolumn{3}{|c|}{ Resistivity $(\Omega \mathrm{m})$} & \multicolumn{2}{|c|}{$\begin{array}{c}\text { Longitudinal } \\
\text { Conductance } \\
\text { (Siemens) }\end{array}$} & \multicolumn{2}{|c|}{$\begin{array}{c}\text { Transverse } \\
\text { Conductance } \\
\left(\Omega \mathrm{m}^{2}\right)\end{array}$} & \multirow[t]{2}{*}{$\begin{array}{c}\text { Fitting } \\
\text { Error }\end{array}$} & \multirow[t]{2}{*}{ Curve Type } \\
\hline & & & $\mathrm{h}_{1}$ & $\mathrm{~h}_{2}$ & $\rho_{1}$ & $\rho_{2}$ & $\rho_{3}$ & $\mathrm{~S}_{1}$ & $\mathrm{~S}_{2}$ & $\mathrm{~T}_{1}$ & $\mathrm{~T}_{2}$ & & \\
\hline 1 & VES 1 & $\mathrm{E}^{\prime} 3^{\circ} 16^{\prime} \mathrm{N} 10^{\circ} 41^{\prime}$ & 3.0 & 13.0 & 100 & 48 & 64 & 0.0301 & 0.270 & 300 & 623 & 2.24 & $\mathrm{H}$ \\
\hline 2 & VES 2 & $\mathrm{E} 13^{\circ} 14^{\prime} \mathrm{N} 10^{\circ} 42^{\prime}$ & 1.0 & 6.0 & 63 & 12 & 346 & 0.013 & 0.474 & 51.9 & 67.7 & 2.44 & $\mathrm{H}$ \\
\hline 3 & VES 3 & $\mathrm{E} 13^{\circ} 12^{\prime} \mathrm{N} 10^{\circ} 42^{\prime}$ & 1.0 & 14.2 & 85 & 36 & 425 & 0.011 & 0.394 & 79.7 & 512 & 2.24 & $\mathrm{H}$ \\
\hline 4 & VES 4 & $\mathrm{E} 13^{\circ} 08^{\prime} \mathrm{N} 10^{\circ} 41^{\prime}$ & 1.1 & 7.6 & 134 & 38 & 222 & 0.008 & 0.198 & 147 & 290 & 2.47 & $\mathrm{H}$ \\
\hline 5 & VES 5 & $\mathrm{E} 13^{\circ} 09^{\prime} \mathrm{N} 10^{\circ} 42^{\prime}$ & 1.0 & 5.4 & 70 & 55 & 313 & 0.011 & 0.099 & 55.9 & 295 & 2.30 & $\mathrm{H}$ \\
\hline 6 & VES 6 & $\mathrm{E} 13^{\circ} 09^{\prime} \mathrm{N} 10^{\circ} 43^{\prime}$ & 1.0 & 16.0 & 204 & 73 & 340 & 0.004 & 0.216 & 175 & 1167 & 2.96 & $\mathrm{H}$ \\
\hline 7 & VES 7 & $\mathrm{E} 13^{\circ} 08^{\prime} \mathrm{N} 10^{\circ} 43^{\prime}$ & 1.0 & 13.0 & 39 & 12 & 246 & 0.024 & 1.080 & 36.9 & 153.8 & 2.66 & $\mathrm{H}$ \\
\hline 8 & VES 8 & $\mathrm{E} 13^{\circ} 10^{\prime} \mathrm{N} 10^{\circ} 44^{\prime}$ & 1.3 & 18.0 & 91 & 41 & 158 & 0.015 & 0.434 & 121 & 715.0 & 2.27 & $\mathrm{H}$ \\
\hline 9 & VES 9 & $\mathrm{E} 13^{\circ} 44^{\prime} \mathrm{N} 10^{\circ} 45^{\prime}$ & 1.0 & 6.40 & 34 & 25 & 203 & 0.028 & 0.257 & 32.3 & 161.0 & 2.45 & $\mathrm{H}$ \\
\hline 10 & VES 10 & $\mathrm{E} 13^{\circ} 12^{\prime} \mathrm{N} 10^{\circ} 46^{\prime}$ & 1.4 & 11.0 & 233 & 109 & 351 & 0.006 & 0.100 & 330 & 1190 & 2.05 & $\mathrm{H}$ \\
\hline 11 & VES 11 & $\mathrm{E} 13^{\circ} 16^{\prime} \mathrm{N} 10^{\circ} 47^{\prime}$ & 1.0 & 14.0 & 578 & 170 & 6599 & 0.002 & 0.080 & 539 & 2321 & 2.99 & $\mathrm{H}$ \\
\hline 12 & VES 12 & $\mathrm{E} 13^{\circ} 16^{\prime} \mathrm{N} 10^{\circ} 47^{\prime}$ & 1.0 & 15.0 & 86 & 36 & 526 & 0.011 & 0.401 & 78.9 & 532 & 2.51 & $\mathrm{H}$ \\
\hline 13 & VES 13 & $\mathrm{E} 13^{\circ} 10^{\prime} \mathrm{N} 10^{\circ} 53^{\prime}$ & 1.3 & 13.3 & 116 & 30.4 & 3264 & 0.011 & 0.438 & 145 & 404 & 4.48 & $\mathrm{H}$ \\
\hline 14 & VES 14 & $\mathrm{E} 13^{\circ} 12^{\prime} \mathrm{N} 10^{\circ} 50^{\prime}$ & 1.0 & 12.4 & 30 & 14 & 63 & 0.029 & 0.887 & 26.8 & 174 & 1.92 & $\mathrm{H}$ \\
\hline 15 & VES 15 & $\mathrm{E} 13^{\circ} 09^{\prime} \mathrm{N} 10^{\circ} 51^{\prime}$ & 1.1 & 10.0 & 21 & 30 & 53 & 0.052 & 0.322 & 22.0 & 290 & 2.51 & $\mathrm{~A}$ \\
\hline 16 & VES 16 & $\mathrm{E}^{\prime} 3^{\circ} 16^{\prime} \mathrm{N} 10^{\circ} 51^{\prime}$ & 1.0 & 8.2 & 220 & 44 & 550 & 0.003 & 0.186 & 156 & 356 & 3.81 & $\mathrm{H}$ \\
\hline 17 & VES 17 & $\mathrm{E} 13^{\circ} 14^{\prime} \mathrm{N} 10^{\circ} 52^{\prime}$ & 1.3 & 39.0 & 30 & 179 & 95 & 0.045 & 0.215 & 39.7 & 6944 & 3.70 & $\mathrm{~K}$ \\
\hline 18 & VES 18 & $\mathrm{E} 13^{\circ} 16^{\prime} \mathrm{N} 10^{\circ} 53^{\prime}$ & 1.0 & 11.1 & 73 & 38 & 813 & 0.0011 & 0.295 & 56.9 & 421 & 3.36 & $\mathrm{H}$ \\
\hline 19 & VES 19 & $\mathrm{E} 13^{\circ} 15^{\prime} \mathrm{N} 10^{\circ} 53^{\prime}$ & 1.0 & 8.5 & 31.4 & 22.3 & 446 & 0.029 & 0.383 & 28.5 & 190 & 2.71 & $\mathrm{H}$ \\
\hline 20 & VES 20 & $\mathrm{E} 13^{\circ} 10^{\prime} \mathrm{N} 10^{\circ} 52^{\prime}$ & 1.0 & 29.0 & 169 & 34 & 923 & 0.006 & 0.833 & 165 & 984 & 3.04 & $\mathrm{H}$ \\
\hline 21 & VES 21 & $\mathrm{E} 13^{\circ} 09^{\prime} \mathrm{N} 10^{\circ} 53^{\prime}$ & 1.0 & 15.0 & 177 & 51 & 261 & 0.005 & 0.283 & 150 & 744 & 3.60 & $\mathrm{H}$ \\
\hline 22 & VES 22 & $\mathrm{E} 13^{\circ} 07^{\prime} \mathrm{N} 10^{\circ} 53^{\prime}$ & 1.0 & 15.0 & 271 & 73 & 166 & 0.003 & 0.201 & 201 & 1068 & 3.44 & $\mathrm{H}$ \\
\hline 23 & Average & & 1.2 & 14.5 & 129.8 & 61.8 & 746.7 & 0.016 & 0.366 & 133.6 & 891 & 2.8 & \\
\hline
\end{tabular}

\section{B. Geo-Electric Section along Profile A-A}

Geo-electric section was drawn along profile A-A' in South to North direction and made up of six (6) Vertical electrical soundings (VES) points. These points are VES 7, VES 9, VES 11, VES 13, VES 20, and VES 21 (Fig. 4 a). The section was constructed by plotting the resistivity obtained as observed along vertical probing surface at each sounding point on a chosen profile and the result was plotted and correlated. These represent subsurface variation in resistivity and depths of different layers along with the profile.
The topsoil is generally thin (about $1 \mathrm{~m}$ thick). The resistivity ranges between $21 \Omega \mathrm{m}$ at VES 15 to $578 \Omega \mathrm{m}$ at VES 11 which corresponds to topsoil composed of Clayed to lateritic sand. The Highly weathered / fractured layer has a varying thickness ranging from $6.4 \mathrm{~m}$ thick at VES 9 to $29 \mathrm{~m}$ at VES 20 with resistivity values of $12 \Omega \mathrm{m}$ at VES 7 to 170 $\Omega \mathrm{m}$ at VES 11 , the third layer has resistivity ranging from $203 \Omega \mathrm{m}$ at VES 9 to $6599 \Omega \mathrm{m}$ at VES 11 with thickness tend to infinity. The third layer at VES 7, 9 and 21 represent partly weather basement while at VES 11, VES 13, and VES 20 depicting the fresh basement zone. 

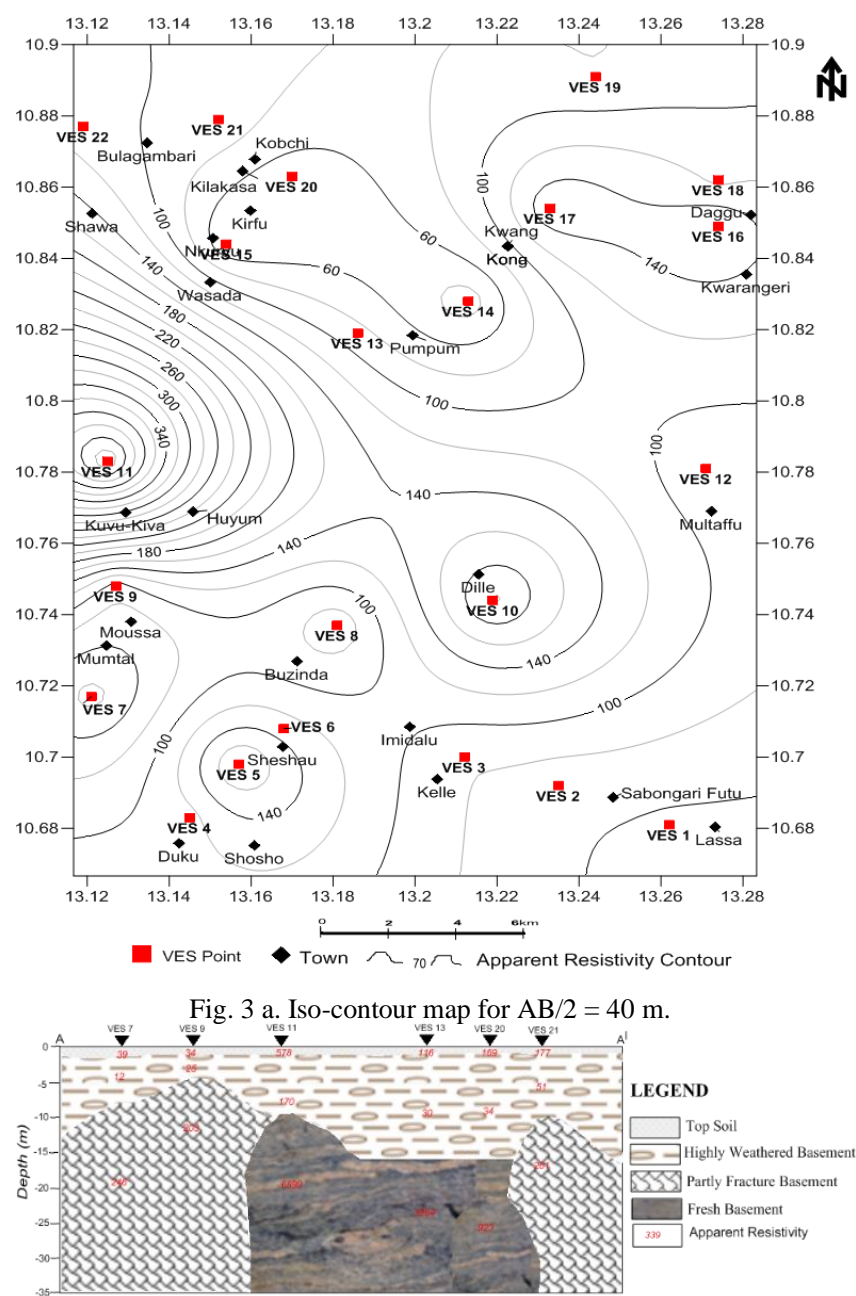

Fig. 4 a. Geoelectro-stratigraphic section profile A-A'.

\section{Geo-Electric Section along Profile B-B}

These represent sub-surface variation in resistivity and depths of different layers along with profile B-B' which consist of five Vertical electrical sounding (VES) points. These points are VES 3, VES 10, VES 12, VES 16, and VES 18 (Fig. 4 b). The topsoil is generally thin about $1 \mathrm{~m}$ thick. The resistivity range between $85 \Omega \mathrm{m}$ at VES 3 to $233 \Omega \mathrm{m}$ at VES 10 . The Highly weathered/fractured layer has a varying thickness ranging from $8.2 \mathrm{~m}$ thick at VES 16 to $15 \mathrm{~m}$ thick at VES 12 with varying resistivity of $36 \Omega$ m at VES 3 to 109 $\Omega \mathrm{m}$ at VES 10 . While the third layer at representing partly fractured granite with a resistivity of $351 \Omega \mathrm{m}$ to $813 \Omega \mathrm{m}$.

The geophysical survey has helped in delineating aquifer zones in the study area. From geoelectro-stratigraphic section (profile A-A' and Profile B-B') revealed three geologic layers beneath the subsurface; the second layer is a highly weathered basement and layer three is partly fracture basement with appreciable thickness suggesting these points are good for borehole drilling (Aquifereous Points); these points include VES 7, 9, 21 (profile A-A') and VES 3, 10, Prof $12,16,18$ (profile B-B'). The highly weathered basement and partly fracture basement layer make up the water bearing formation of the area.

\section{Aquifer Parameters Estimated from Geophysical Data}

Dar Zarrouk was used to evaluate protective capacity of the area. Total overburden thickness provides protection by decreasing infiltration time of contaminant from the surface

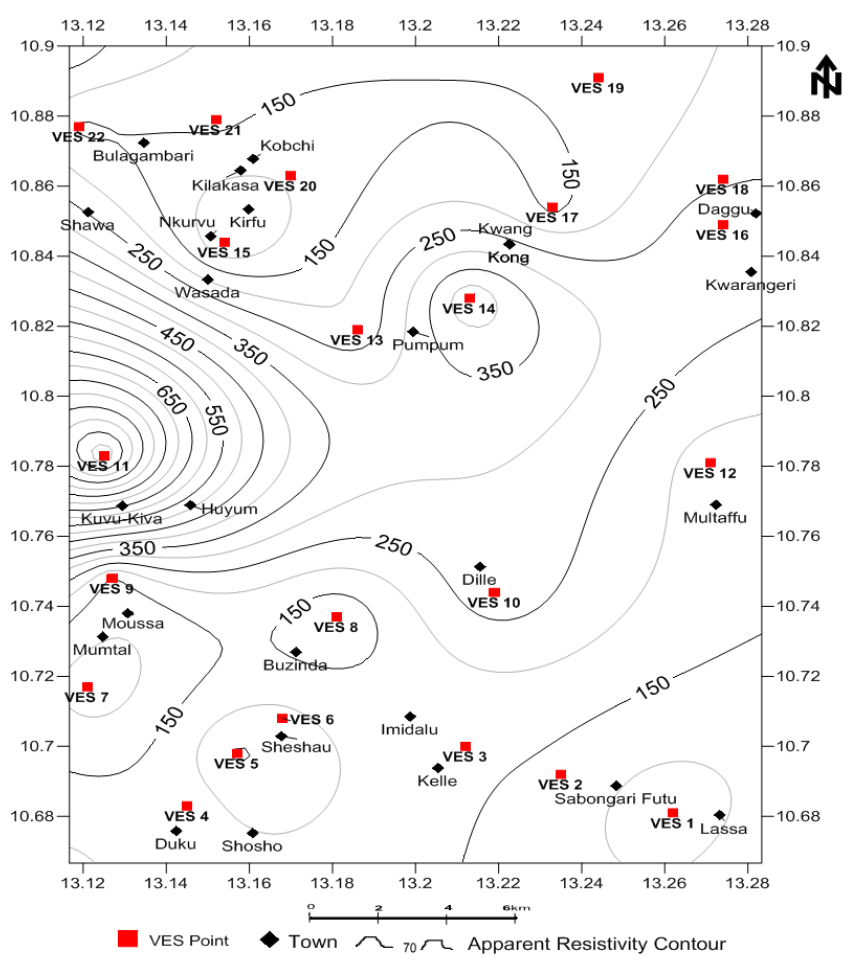

Fig. 3 b. Iso-contour map for $\mathrm{AB} / 2=100 \mathrm{~m}$.

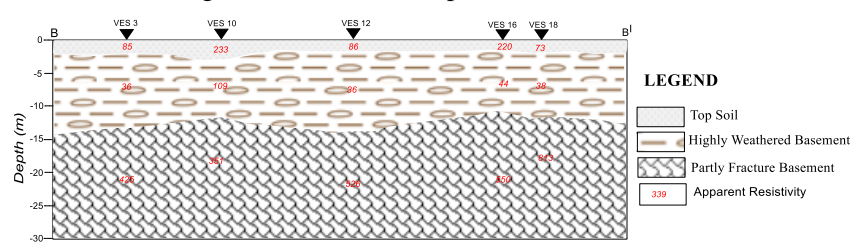

Fig. 4 b. Geoelectro-stratigraphic section profile B-B'.

into groundwater [10]. "An aquifer protection capacity rating can be classified on the basis of the total longitudinal unit conductance $(\Sigma \mathrm{S})$ as excellent $(\mathrm{S}>10)$, very good $(5 \leq \mathrm{S} \leq$ $10)$, good $(0.7 \leq \mathrm{S}<5)$, moderate $(0.2 \leq \mathrm{S}<0.7)$, weak $(0.1 \leq$ $\mathrm{S}<0.2)$ and poor $(\mathrm{S}<0.1)$ protective capacity".

VES 7, 14, and 20 showed good protective capacity with $13.6 \%$ over the study area. $72.7 \%$ have moderate capacity which comprises of VES 1, 2, 3, 4, 6, 8, 9, 11, 13, 15, 16, 17, $18,19,21$, and 22 while VES 5, 10, and 11 (13.6\%) showed weak protective capacity of the overburden materials. Areas that are classified as poor and weak are indicative areas are thus vulnerable to infiltration of leachate and other surface contaminations (Fig. 5a).

Transverse resistance is also used to define areas of groundwater potentials [11]. A resistance layer can be determined by transverse resistance. The transvers resistance within the study area ranges from 119.6 to $6983.7 \mathrm{ohms}-\mathrm{m}^{2}$ with average value of 1024.59 ohms-m ${ }^{2}$ (Fig. 5 b). High transvers resistance within the study area is in North-eastern part of the area.

The aquifer parameters calculated from geophysical data like hydraulic conductivity $(\mathrm{K})$ and transmissivity $(\mathrm{T})$ are important for the management and development of groundwater resources. The hydraulic conductivity was estimated using the equation as given by [12] and the summary of Aquifer Parameters estimated from Geophysical Data are presented in Table II. 


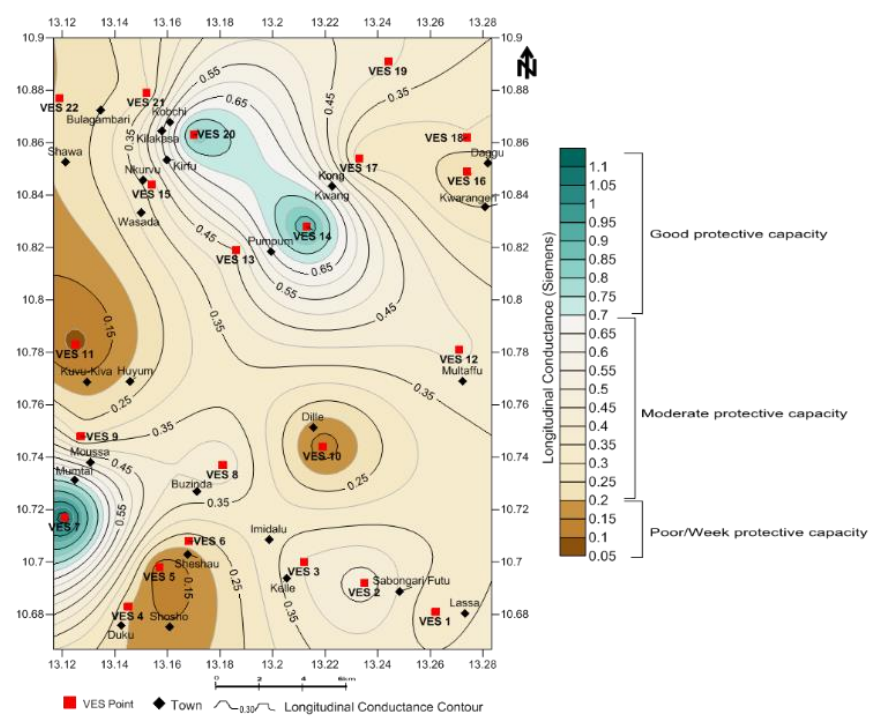

Fig. 5 a. Protective capacity contour map of the study area.

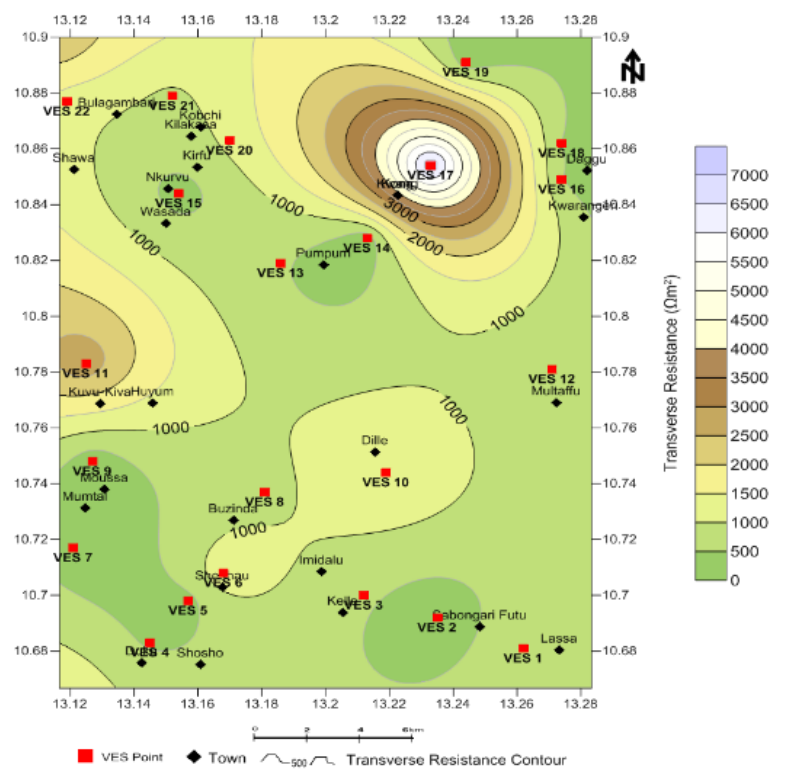

Fig. 5 b. Transvers resistance contour map.

TABLE II: AQUIFER PARAMETERS ESTIMATED FROM GEOPHYSICAL DATA

\begin{tabular}{|c|c|c|c|c|c|c|}
\hline $\begin{array}{l}\mathrm{S} / \\
\mathrm{N}\end{array}$ & VES Point & $\begin{array}{c}\text { Layer } \\
\text { thickness }(\mathrm{m})\end{array}$ & $\begin{array}{c}\text { Layer Resistivity } \\
(\Omega \mathrm{m})\end{array}$ & $\mathrm{K}_{\mathrm{c}}$ (m/day) & $\mathrm{T}_{\mathrm{c}}\left(\mathrm{m}^{2} /\right.$ day $)$ & $\begin{array}{c}\text { Groundwater } \\
\text { Potential }\end{array}$ \\
\hline 1 & VES 1 & 13 & 48 & 10.44 & 135.72 & Moderate \\
\hline 2 & VES 2 & 6 & 12 & 38.04 & 228.24 & Moderate \\
\hline 3 & VES 3 & 14.2 & 36 & 13.65 & 193.83 & Moderate \\
\hline 4 & VES 4 & 7.6 & 38 & 12.98 & 98.64 & Moderate \\
\hline 5 & VES 5 & 5.4 & 55 & 9.1 & 49.14 & Low \\
\hline 6 & VES 6 & 16 & 78 & 6.63 & 106.08 & Moderate \\
\hline 7 & VES 7 & 13 & 12 & 38.04 & 494.52 & Moderate \\
\hline 8 & VES 8 & 18 & 41 & 12.09 & 217.62 & Moderate \\
\hline 9 & VES 9 & 6.4 & 25 & 19.18 & 122.75 & Moderate \\
\hline 10 & VES 10 & 11 & 109 & 4.85 & 53.35 & Low \\
\hline 11 & VES 11 & 14 & 170 & 3.20 & 44.8 & Low \\
\hline 12 & VES 12 & 15 & 36 & 13.65 & 204.75 & Moderate \\
\hline 13 & VES 13 & 13.3 & 30.4 & 15.98 & 212.53 & Moderate \\
\hline 14 & VES 14 & 12.4 & 14 & 32.95 & 408.58 & Moderate \\
\hline 15 & VES 15 & 10 & 30 & 16.18 & 161.8 & Moderate \\
\hline 16 & VES 16 & 8.2 & 44 & 11.32 & 92.82 & Moderate \\
\hline 17 & VES 17 & 39 & 179 & 3.05 & 118.95 & Moderate \\
\hline 18 & VES 18 & 11.1 & 38 & 12.98 & 144.07 & Moderate \\
\hline 19 & VES 19 & 8.5 & 22.3 & 21.34 & 181.39 & Moderate \\
\hline 20 & VES 20 & 29 & 34 & 14.40 & 417.6 & Moderate \\
\hline 21 & VES 21 & 15 & 51 & 9.86 & 147.9 & Moderate \\
\hline 22 & VES 22 & 15 & 73 & 7.06 & 105.9 & Moderate \\
\hline \multicolumn{2}{|c|}{ Average Value } & 13.68 & 53.44 & 14.86 & 179.13 & \\
\hline
\end{tabular}

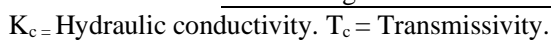

$>500$ High potential, 60-500 Moderate potential, 6-59 Low potential, 0.5-5 Very low potential, <0.5 Negligible potential.

Hydraulic conductivity is proportional to permeability. High permeability will be observed in aquifer zone with high hydraulic conductivity and also contaminants will be easily circulated. The hydraulic conductivity estimated from the electrical resistivity sounding data was contoured as shown in (Fig. 6 a). Hydraulic conductivity values determined from geoelectrical technique range from 3.05 to $38.04 \mathrm{~m} /$ day with average value of $14.86 \mathrm{~m} / \mathrm{day}$. Fig. $6 \mathrm{~b}$ shows the Transmissivity values obtained from VES method for potential aquifers range between 44.8 to $494.52 \mathrm{~m}^{2} /$ day with an average of $179.13 \mathrm{~m}^{2} /$ day. High transmissivity values correspond to high groundwater potential and these areas correspond to high hydraulic potential zones.

Pearson Correlation measures the degree of a linear relationship between two variables. The correlation coefficient assumes a value between -1 and +1 [13]. If one variable tends to increase as the other decreases, the correlation coefficient is negative. Conversely, if the two variables tend to increase together the correlation coefficient is positive. The larger the absolute value of the coefficient, the stronger the relationship between the variables.

For the Pearson correlation, an absolute value of 1 indicates a perfect linear relationship. A correlation close to 0 indicates no linear relationship between the variables. The sign of the coefficient indicates the direction of the relationship. If both variables tend to increase or decrease together, the coefficient is positive, and the line that represents the correlation slopes upward. If one variable tends to increase as the other decreases, the coefficient is negative, and the line that represents the correlation slopes downward.

The Pearson correlation coefficient between transmissivity and Hydraulic conductivity is 0.73 and represents a positive relationship and strong correlation between the variables. As transmissivity increases, Hydraulic conductivity also increases. 


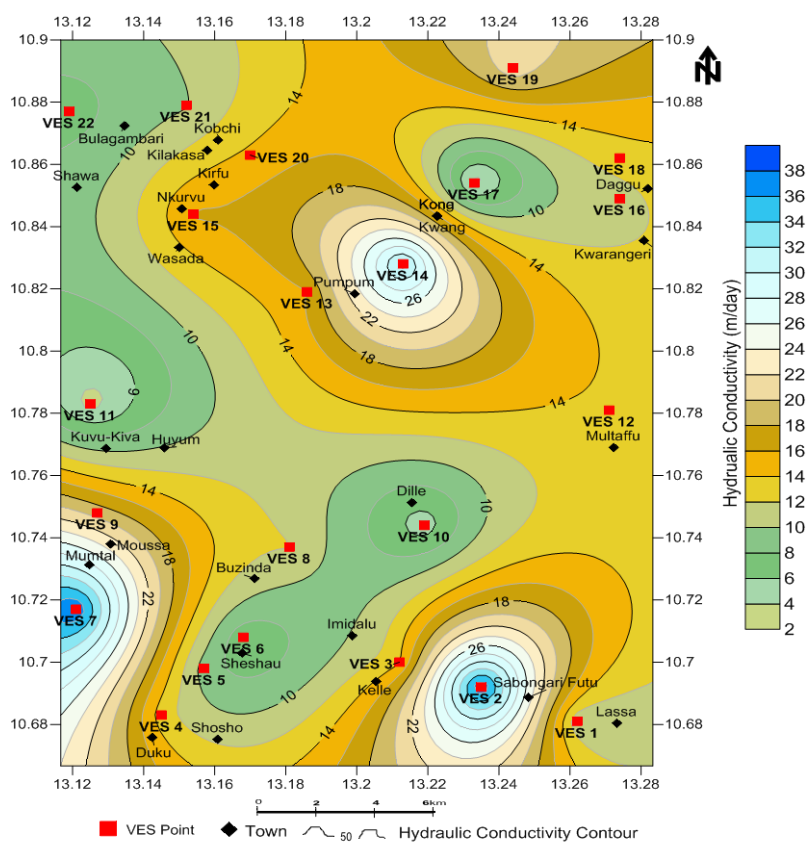

Fig. 6a: Hydraulic conductivity contour map.

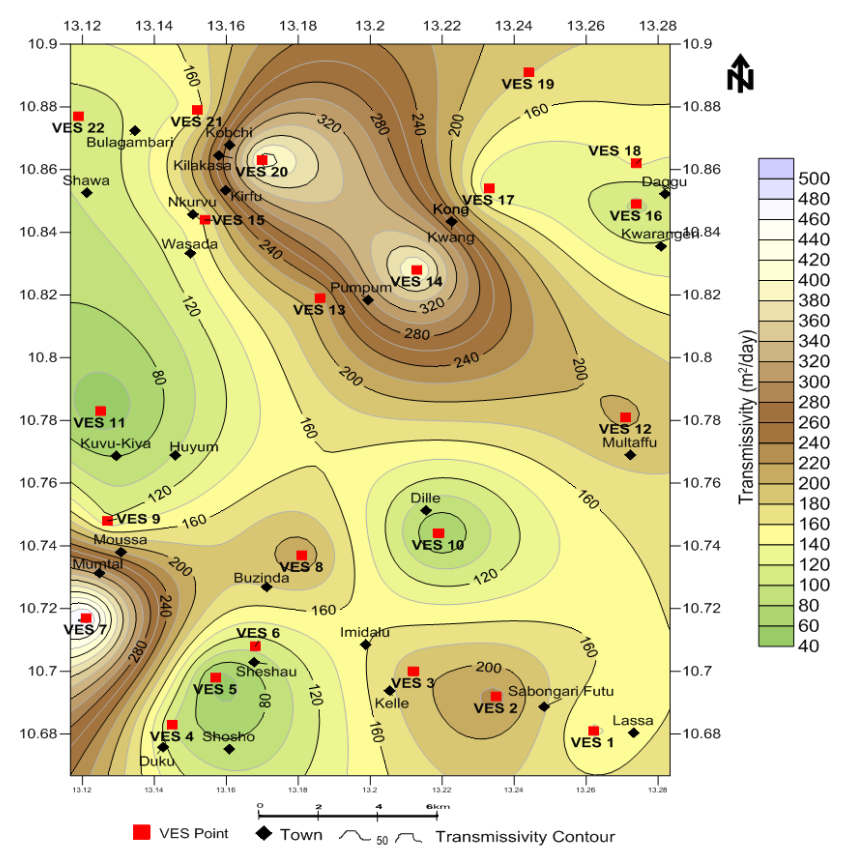

Fig. 6 b. Transmissivity contour map.

Fig. 7 therefore, shows a good correlation between hydraulic conductivity and transmissivity are given the Pearson correlation $=0.73$. This signifies that hydraulic conductivity is directly proportional to transmissivity.

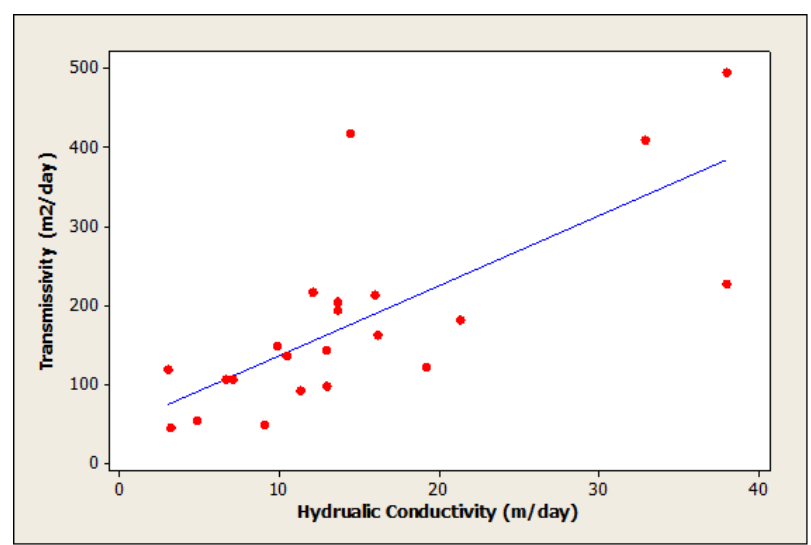

Fig. 7. Correlation between transmissivity and hydraulic conductivity.

\section{CONCLUSION}

Geo-electrical study of the area using the Schlumberger method has assisted in delineating groundwater potential zone of Lassa and Environs. Information gathered from an interpretation of twenty two Vertical electrical soundings in this area showed that H-type curve is the most prominent depicting three-layer earth model. Highly weathered and partly fracture basement have been identified and these constitute the aquifer zone. $13.6 \%$ showed good protective capacity, $72.7 \%$ have moderate capacity while $13.6 \%$ showed weak protective capacity of the overburden materials. High transvers resistance within the study area is in North-eastern part of the area. Hydraulic conductivity values determined from geoelectrical technique range from 3.05 to $38.04 \mathrm{~m} /$ day with an average value of $14.86 \mathrm{~m} /$ day. Transmissivity values obtained from VES method for potential aquifers range between 44.8 to $494.52 \mathrm{~m}^{2} /$ day with an average of $179.13 \mathrm{~m}^{2} /$ day. High transmissivity values correspond to high groundwater potential and this area corresponds to hydraulic potential zones.

\section{CONFLICT OF INTEREST}

The authors declare that they have no conflict of interest.

\section{REFERENCES}

[1] V. A. Akinbinu, "Delineation of saline water intrusion to safe-inland groundwater resource," Ocean Coastal Manag, vol. 116, pp. 162-168, 2015.

[2] B. D. Ako and M. O. Olorunfemi, "Geo-electric survey for groundwater in newer basalt of Vom, Plateau State," Journal of Geology and Mining, vol. 25, pp. 247-249, 1989.

[3] M. R. Islam, S. Ostaficzuk, and S. Baba, The Geology of the basement complex of Northern part of the Mandara Hills, Nigeria annual of Borno Vol. VI/VII, University of Maiduguri press, pp. 23-25, 1989.

[4] J. D. Carter, "Rocks and field assessment," pp. 30-34, 1963.

[5] M. O. Olorunfemi, and S. A. Fasuyi, "Aquifer types and the geoelectric /Hydrogeologic characteristics of part of the central basement Terrain of Nigeria (Niger State)," Journal of African Earth Science, vol. III, pp. 27-33, 1993.

[6] A. I. Olayinka, "Non uniqueness in the interpretation of Bed rock resistivity from sounding curves and hydrological implications," Journal of Nigeria association of hydrologist, vol. 7 (1\&2). pp. 49-55, 1996.

[7] A. E. Edet, and C. S. Okereke, "Assessment of hydrogeological conditions in Basement Aquifers of the Precambrian Oban Massif, Southeastern Nigeria," J. Appl. Geophys, vol. 36, pp. 95-204, 1997.

[8] A. Nur, and K. N. Ayuni, "Hydrogeophysical study of Minchika and environs, NE Nigeria," International Journal of the Physical Sciences, vol. 6(34), pp. 7816-7827, 2011.

[9] A. Nur and H. I. Matazu, "Hydrogeo-electrical investigation of Fufore and its Environs of Adamawa State, North-eastern Nigeria," International Journal of Earth Sciences and Engineering (IJEE), Hyderabad, India; vol. 04 (5), pp. 796-806, 2011.

[10] I. S. Nggada and A. Nur, "Geo-electrical survey for groundwater potential of Biu and Environs, North Eastern Nigeria," World Journal of Applied Physics, vol. 2, no. 5, pp. 59-70, 2017. doi: 10.11648/j.wjap.20170205.11.

[11] G. Cassiani, and M. A. Medina Jr, "Incorporating auxiliary geophysical data into groundwater flow parameter estimation," Groundwater, vol. 35, pp. 79-91, 1997.

[12] P. C. Heigold, R. H. Gikeson, K. Cartwright, and P. C. Reed, “Aquifer transmissivity from surficial electrical methods," Groundwater, 17(4), 338-345, 1979.

[13] A. G. Bluman, "Elementary Statistics, A step by step Approach," (2nd Ed.), Mc Graw-Hill, N. York, 637p, 2003. 